\title{
Serum total cholesterol and ferritin and blood haemoglobin concentrations in primary schoolchildren
}

\author{
Judith Hammond, Susan Chinn, Heather Richardson, Roberto Rona
}

\begin{abstract}
Serum total cholesterol and ferritin and haemoglobin concentrations were measured in blood samples obtained by venepuncture in 378 of 593 children aged 5-6 or 8-9 years from seven primary schools in Canterbury. This study formed part of an investigation to assess the feasibility of including a venepuncture procedure for monitoring purposes in primary schoolchildren.

Although only one child had a very low haemoglobin concentration of $61 \mathrm{~g} / \mathrm{l}$, a large percentage, $25 \%$ in the rising 6 years and $7 \%$ in the rising 9 years, had concentrations between 100 and $115 \mathrm{~g} / \mathrm{l}$ - that is, less than the reference fifth centile. Eight per cent had a serum ferritin concentration less than $8 \mu \mathrm{g} / \mathrm{l}$. Cholesterol concentrations higher than $5.2 \mathrm{mmol} / \mathrm{l}$ were found in $20 \%$ of the 5-6 year olds and $23 \%$ of the 8-9 year olds, and in $19 \%$ of boys and $25 \%$ of girls. About $5 \%$ of children had cholesterol concentrations above $6 \mathrm{mmol} / \mathrm{l}$.

The number of children with anaemia, iron deficiency, and high cholesterol raises serious concerns about the nutritional and coronary heart disease risk of British children.

(Arch Dis Child 1994; 70: 373-375)
\end{abstract}

In Britain assessment of the nutritional status of children has been based solely on anthropometric measurements of height, weight, and skinfold thickness. The recognition that increased serum total cholesterol is a major risk factor for coronary heart disease, ${ }^{12}$ that coronary heart disease is a major killer in Britain, ${ }^{3}$ and that atherosclerosis may begin in childhood $^{4}$ leads to a strong argument for monitoring cholesterol concentrations in children. Cholesterol concentrations have been studied in the $\mathrm{USA}^{56}$ and many other countries. ${ }^{7}$ Knuiman et al published cholesterol concentrations for 16 countries as early as $1980,{ }^{7}$ but no substantial epidemiological information has been available for children in Britain.

In a study of the feasibility of venepuncture in primary schools we were also interested to ascertain the need for monitoring iron deficiency in Britain. Screening for anaemia has been the most common laboratory assessment, internationally, of nutritional status in children. ${ }^{8}$ Although iron deficiency is the most common nutritional deficiency in children, 9 several reports in the USA and Canada have indicated that the frequency of iron deficiency has decreased over the last 20 years. ${ }^{9-12}$ In Britain, however, several studies have reported iron deficiency in preschool and adolescent children. ${ }^{13-17}$

The objective of this study was to ascertain whether serum concentrations of cholesterol and iron are a cause of concern in the health of British children.

\section{Subjects and methods}

The sample consisted of 378 children aged 5-6 years or 8-9 years whose parents gave consent to venepuncture and who themselves agreed and were able to provide a sample at the time, as described in the accompanying paper. ${ }^{18}$

Blood samples were analysed for haemoglobin using a Coulter JS analyser. Serum ferritin concentrations were measured using a monoclonal antibody solid phase component system from Becton Dickinson. Serum total cholesterol concentrations were measured using an automated cholesterol oxidase-peroxidase method with kits supplied by BoehringerMannheim. A Lobas Bio centrifugal analyser was used with single point calibration of the machine with a serum based standard traced to Centers for Disease Control reference material. This standard was run in duplicate in each batch, together with internal quality assurance samples of known value (low, medium, and high). External quality assurance was performed using the UKEQAS and Wellcome schemes, which cover laboratories using a similar system. Insufficient serum was available for complete testing for three samples, for which cholesterol concentrations were available, but not haemoglobin and ferritin. The samples were sent by first class post from Canterbury to a laboratory in Newcastle.

Abnormal results were reported to parents and general practitioners through a local medical collaborator, who stressed the need for reassessment.

\section{ANALYSIS}

The means, standard deviations, and distributions of the haemoglobin and cholesterol results were described for the total sample, the two sexes, and the two age groups. Where the results were clearly skewed, data were transformed to a $\log$ scale before analysis and hence the geometric mean and $95 \%$ range are reported for ferritin results. Percentages of children with values below or above cut off
Dr Rona.

Accepted 20 January 1994 
Table 1 Serum haemoglobin and ferritin results by sex and age. Values are number (\%) of children

\begin{tabular}{lcccc}
\hline & $\begin{array}{l}\text { Boys } \\
(n=198)\end{array}$ & $\begin{array}{l}\text { Girls } \\
(n=177)\end{array}$ & $\begin{array}{l}\text { Rising 6 } \\
\text { years } \\
(n=163)\end{array}$ & $\begin{array}{l}\text { Rising } 9 \\
\text { years } \\
(n=206)\end{array}$ \\
\hline $\begin{array}{l}\text { Haemoglobin }(\mathrm{g} / \mathrm{l}) \\
\quad<115\end{array}$ & $36(18)$ & $23(13)$ & $41(25)$ & $15(7)$ \\
$\quad 115$ & $162(82)$ & $154(87)$ & $122(75)$ & $191(93)$ \\
$\begin{array}{l}\text { Ferritin }(\mu \mathrm{g} / \mathrm{l}) \\
\quad<8\end{array}$ & $16(8)$ & $15(8)$ & $17(10)$ & $13(6)$ \\
$\geqslant 8$ & $182(92)$ & $162(92)$ & $146(90)$ & $193(94)$ \\
\hline
\end{tabular}

Total number varies between sex and age groups as ages were not recorded for six children. Total number for haemoglobin and ferritin results is smaller than for cholesterol results as insufficient blood was available for all analyses on some children.

points were compared between age groups using the $\chi^{2}$ test.

\section{Results}

Results for serum ferritin and serum haemoglobin are given by sex and age in table 1 and serum cholesterol concentrations in table 2 .

Compared with the reference values developed by Dallman and Siimes, ${ }^{19}$ the mean haemoglobin value for this group of children was low (122 $\mathrm{g} / \mathrm{l}$ compared with 130 $\mathrm{g} / \mathrm{l})$ and $23(13 \%)$ girls and $36(18 \%)$ boys had haemoglobin values less than the fifth centile of $115 \mathrm{~g} / \mathrm{l}$. Only one child had a haemoglobin result less than $100 \mathrm{~g} / \mathrm{l}$. The percentage of children with haemoglobin less than $115 \mathrm{~g} / 1$ was higher in 6 year old children (25\%) than in 9 year olds $(7 \%)(p<0.001)$; the $95 \%$ confidence interval for the difference in percentages was from 10 to $25 \%$. Four children with a cholesterol concentration greater than $6.5 \mathrm{mmol} / \mathrm{l}$ and a child with a haemoglobin of $61 \mathrm{~g} / 1$ and serum ferritin of 5 $\mu \mathrm{g} / \mathrm{l}$ were considered to have abnormal results, which were reported to their parents and general practitioners.

The ferritin results were skewed to the right but were approximately normally distributed when log transformed. The geometric mean (and 95\% range) for serum ferritin was $17 \cdot 4$ $(5 \cdot 4-56 \cdot 6) \mu \mathrm{g} / 1$ for boys and $17 \cdot 0(5 \cdot 8-49 \cdot 9)$ $\mu \mathrm{g} / \mathrm{l}$ for girls. Eighteen per cent of boys and $20 \%$ of girls had serum ferritin concentrations $\leqslant 10 \mu \mathrm{g} / \mathrm{l}$ and $8 \%$ of boys and girls had serum ferritin $\leqslant 8 \mu \mathrm{g} / \mathrm{l}$, representing iron deficiency. When log ferritin was plotted against haemoglobin results, lower haemoglobin results (less than $110 \mathrm{~g} / \mathrm{l}$ ) were associated with lower serum ferritin concentrations for girls, but there was little association for boys, with the exception of a child with a serum ferritin concentration of $5.0 \mu \mathrm{g} / \mathrm{l}$ and haemoglobin concentration of $61 \mathrm{~g} / \mathrm{l}$. Low concentrations of

Table 2 Serum cholesterol results by sex and age. Values are number (\%) of children

\begin{tabular}{llllc}
\hline $\begin{array}{l}\text { Serum cholesterol } \\
(\text { mmoll })\end{array}$ & $\begin{array}{l}\text { Boys } \\
(n=200)\end{array}$ & $\begin{array}{l}\text { Girls } \\
(n=178)\end{array}$ & $\begin{array}{l}\text { Rising 6 } \\
\text { years } \\
(n=165)\end{array}$ & $\begin{array}{l}\text { Rising 9 } \\
\text { years } \\
(n=207)\end{array}$ \\
\hline$<5.2$ & $162(81)$ & $133(75)$ & $132(80)$ & $159(77)$ \\
5.2 to $<6.0$ & $32(16)$ & $33(19)$ & $23(14)$ & $40(19)$ \\
$\geqslant 6.0$ & $6(3)$ & $12(7)$ & $10(6)$ & $8(4)$ \\
\hline
\end{tabular}

Total number varies between sex and age groups as ages were not recorded for six children. ferritin, less than $8 \mu \mathrm{g} / \mathrm{l}$, were slightly more prevalent in 6 year olds $(10 \%)$ than in 9 year olds $(6 \%)$, but the difference was not statistically significant; the $95 \%$ confidence interval for the difference in prevalence was from -0.2 to $10 \%$.

Twenty two per cent of the children tested had serum cholesterol concentrations greater than $5.2 \mathrm{mmol} / \mathrm{l}$. Eighteen children ( $5 \%$ ) had serum cholesterol results greater than $6 \cdot 0$ $\mathrm{mmol} / \mathrm{l}$. Four per cent of the total sample of children had results between 6.0 and 6.5 $\mathrm{mmol} / \mathrm{l}$ and $1 \%$ had results between 6.5 and $7.0 \mathrm{mmol} / \mathrm{l}$. These higher cholesterol results were equally spread between the sexes and the two age groups. Mean cholesterol concentrations were similar for boys and girls and for the two age groups tested.

\section{Discussion}

The mean cholesterol concentration for the total sample of children $(4.63 \mathrm{mmol} / \mathrm{l})$ was higher than that found in a sample of children aged 8-11 years whose capillary blood samples were analysed using a portable cholesterol analyser by the same workers in 1991 (mean (SD) cholesterol $4.34 \quad(0.65) \quad \mathrm{mmol} / \mathrm{l}$; Hammond J, Chinn S, Rona R, unpublished data) and higher than those of hospital ${ }^{20}$ and community based ${ }^{21}$ studies of children in Britain, children living in the USA, ${ }^{56}$ and in 16 other countries. ${ }^{7}$ The results are similar to those found by Armstrong et al (mean age of sample 12.8 years) ${ }^{22}$ and Sporik et al (sample aged 11 years) ${ }^{23}$ in studies of British children. Such comparisons between studies are limited by the lack of standardisation between the an lytical methods used to determine cholesterol levels. ${ }^{24-26}$ The laboratory in Newcastle was not part of our previous method comparison study. ${ }^{24}$

We believe this is the first British study to report serum cholesterol results from a sample of healthy children in the primary school age group.

We have used the haemoglobin centiles developed by Dallman and Siimes ${ }^{19}$ as reference values for this paper. These centiles were developed from multiple samples of white children from both the USA and Finland, which excluded results of children with an identified cause of anaemia or iron deficiency in all but one of the samples. The number of children with haemoglobin concentrations less than $115 \mathrm{~g} / \mathrm{l}$ was larger than we had anticipated for predominantly white, middle class children. The mean haemoglobin concentrations were $8 \mathrm{~g} / \mathrm{l}$ lower than those found by Dallman and Siimes ${ }^{19}$ and in the NHANES II study of American children in $1976-80 .{ }^{27}$

Serum ferritin has been shown to reflect total iron stores and is a practical marker to assess in children as it can be measured from small amounts of blood, shows no diurnal variation, and children are not required to fast before blood sampling, unlike serum iron and total iron binding concentration measurements. ${ }^{28}$ As ferritin results are not 
normally distributed they are best described by median or geometric mean values. Dallman and Reeves ${ }^{27}$ suggest that a ferritin concentration less than $10 \mu \mathrm{g} / \mathrm{l}$ at any age is indicative of the depletion of iron stores, whereas Hinchcliffe and Lilleyman use $8 \mu \mathrm{g} / \mathrm{l}$ as evidence of iron deficiency in children in the rising 6 year age group. ${ }^{29}$

The red cell indices of mean corpuscular volume and mean corpuscular haemoglobin are sensitive to changes in nutritional status. ${ }^{28}$ As these indices are readily measured in combination with haemoglobin at little extra cost or effort, the inclusion of these variables in a monitoring system should be considered. In our study the delay between venepuncture and analysis of the sample militated against the inclusion of mean corpuscular volume and mean corpuscular haemoglobin.

Whether screening for anaemia should constitute part of a child health surveillance programme for British children has also been a source for some debate. Several studies have reported significant numbers of children with iron deficiency and anaemia. ${ }^{13-17}$ The levels of anaemia and iron deficiency in these studies were similar to or higher than those found in this study. Those studies reporting higher levels included infants in their samples. It is possible that the prevalence of anaemia decreases between the age of 6 years and puberty, as in our study the percentage of children with haemoglobin less than $115 \mathrm{~g} / 1$ was markedly lower in the older age group, and the prevalence of anaemia in the younger age group is similar to results reported for preschool children. ${ }^{1314} 16$ Few studies have included children of the age range assessed in this study. If our results are representative of a sample of otherwise healthy children, important questions are raised about the state of their health and nutrition, especially as the results from our study had a bias towards children from higher socioeconomic groups and included few children from ethnic minorities among whom nutritional anaemias are known to be more prevalent. ${ }^{30}$

The full extent of the health effects of iron deficiency and anaemia in children remains uncertain. Deficits in growth, psychomotor development, and behaviour have been described with iron deficiency anaemia ${ }^{31-33}$ and this should be an important consideration in making a decision about the inclusion of iron deficiency in a nutritional monitoring system.

Results obtained from this study suggest that an apparently healthy sample of predominantly middle class British children have moderately high levels of iron deficiency, anaemia, and higher than desirable serum cholesterol levels. Inclusion of these variables in surveillance studies of the health and growth of British children in the future is important and the development of reference values based on samples of British children is desirable.

We thank Dr M Laker, reader and consultant of the departmen of clinical biochemistry at the University of Newcastle upon Tyne, Dr K Thida, senior registrar in community paediatrics,
Canterbury, and the head teachers and children of the schools who participated in the study for their help and cooperation. The study was funded by the Department of Health.

1 Kennel WB, Castell WP, Gordon T, McNamara PM. Serum cholesterol lipoproteins and risk of coronary heart disease: the Framingham study. Ann Intern Med 1971; 74: $1-12$.

2 Shaper AG. Coronary heart disease: risks and reasons. London: Current Medical Literature, 1988.

3 Office of Population Censuses and Surveys. Mortality statistics, VS3. Death by cause: 1991 registrations. London: OPCS, 1992.

4 Newman WP, Freedman DS, Voors DW, et al. Relation of serum lipoprotein levels and systolic blood pressure to early atherosclerosis (the Bogalusa study). $N$ Engl $f$ Med 1986; 314: 138-44.

5 Cresanta J,, Srinivasan SR, Foster TA, Webber LS, Berenson GS. Serum lipoprotein levels in children: epidemiologic and clinical implications. F Chronic Dis 1982; 35: 41-51.

6 Resnicow K, Morley-Kotchen J, Wynder E. Plasma cholesterol levels of 6585 children in the United States: results of the know your body screening in five states. Pediatrics 1989; 84: 969-76.

7 Knuiman JT, Hermus RJ, Hautvast JAJG. Serum total and high density lipoprotein (HDL) cholesterol concentrations in rural and urban boys from 16 countries. Atherosclerosis 1980; 36: 529-37.

8 Nathan DG, Oski FA. Iron deficiency and related nutritional anaemias. In: Nathan DG, Oski FA, eds. Haematology of infancy and childhood. Vol 1. 2nd Ed. Philadelphia: Saunders, 1982: 298-327.

9 Baker SJ, DeMaeyer EM. Nutritional anaemia: its understanding and control with special reference to the work of the World Health Organisation. Am $\mathcal{F}$ Clin Nutr 1979; 32: 368-417.

10 Dallman PR, Yip R. Changing characteristics of childhood anemia. F Pediatr 1989; 114: 161-4.

11 Miller V, Swaney S, Deinard AS. Impact of the WIC program on the iron status of infants. Pediatrics 1985; 75: 100-5.

12 Yip R, Walsh KM, Goldfarb MG, Binkin NJ. Declining prevalence of anemia in childhood in a middle class setting: a paediatric success story? Pediatrics 1987; 80: 330-4.

13 Mills A. Iron deficiency in children. $B M \mathcal{F} 1989 ; 299: 124-5$

14 James J, Evans J, Male P, Pallister C, Hendrik JK, Oakhill A. Iron deficiency in inner city pre-school children: development of a general practice screening programme. f $R$ Coll Gen Pract 1988; 38: 250-2.

15 Summons A, Elton P, Evans D. Iron deficiency in adolescents. BMF 1989; 298: 1521 .

16 Grant G. Prevalence of iron deficiency in rural preschool children. Br $\mathcal{F}$ Gen Practice 1990; 40: 112-3.

17 Earley A, Valman HB, Altman DG, Pippard MJ. Microcytosis, iron deficiency, and thalassaemia in preschool children. Arch Dis Child 1990; 65: 610-4.

18 Hammond J, Chinn S, Richardson H, Rona RJ. Response to venepuncture for monitoring in primary schools. Arch Dis Child 1994; 70: 367-72.

19 Dallman PR, Siimes MI. Percentile curves for haemoglobin and red cell volume in infancy and childhood. $\mathcal{F}$ Pediatr 1979; 94: 26-31.

20 Leonard JV, Fosbrooke AS, Lloyd JK, and Wolff OH. Screening for familial B hyperlipoproteinemia in children in hospital. Arch Dis Child 1976; 51: 842-7.

21 Grant G. Surveillance of iron deficiency, anemia and hypercholesterolaemia in rural preschool children. $\mathfrak{F} R$ Coll Gen Pract 1989; 324: 302-3.

22 Armstrong N, Balding J, Gentle P, Kirby B. Estimation of coronary risk factors in British children: a preliminary report. Br $\mathcal{F}$ Sports Med 1992; 24: 61-6.

23 Sporik R, Johnstone JH, Cogswell JJ. Longitudinal study of cholesterol values in 68 children from birth to 11 years of age. Arch Dis Child 1991; 66: 134-7.

24 Hammond J, and Rona RJ. Consensus on cholesterol. BMF 1991; 302: 1209.

25 Roberts L. Measuring cholesterol - is it as tricky as lowering it? Science 1987; 12: 482-3.

26 MacMillan TA, Warnick GR. Interlaboratory proficiency survey of cholesterol and high density lipoprotein cholesterol measurement. Clin Chem 1988; 34: 1629-32.

27 Dallman PR, Reeves JD. Laboratory diagnosis of iron deficiency. In: Stekel A, ed. Iron nutrition in infancy and childhood. New York: Raven Press, 1984: 11-44.

28 Duggan MB, Steel G, Elyws G, Harbottle L, Noble C. Iron status, energy intake, and nutritional status of healthy young adults. Arch Dis Child 1991; 66: 1386-9.

29 Hinchcliffe RF, Lilleyman IS. Practical paediatric haematology: laboratory worker's guide to blood disorders in children. 1987.

30 Willoughby MLN. Paediatric haematology. Edinburgh: Churchill Livingstone, 1977: 7.

31 Walter T, De Andraca I, Chadud P, Perales CG. Iron deficiency anaemia: adverse effects on infant psychomotor development. Pediatrics 1989; 84: 7-17.

32 Aukett MA, Parks YA, Scott PH, Wharton BA. Treatment with iron increases weight gain and psychomotor development. Arch Dis Child 1986; 61: 849-57.

33 Oski FA, Honig AS, Helu B, Howanitz B. Effect of iron therapy on behaviour performance in nonanaemic, iron deficient infants. Pediatrics 1983; 71: 877-80. 